\title{
Speciation Analysis of Labile and Total Silver(I) in Nanosilver Dispersions and Environmental Waters by Hollow Fiber Supported Liquid Membrane Extraction
}

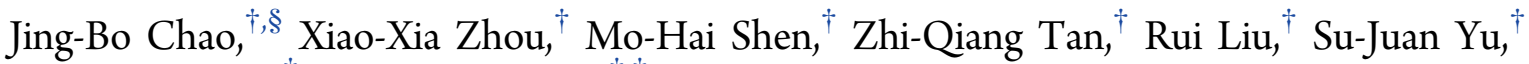 \\ Xiao-Wei Wang, ${ }^{\dagger}$ and Jing-Fu Liu ${ }^{*}$, , \\ ${ }^{\dagger}$ State Key Laboratory of Environmental Chemistry and Ecotoxicology, Research Center for Eco-Environmental Science, Chinese \\ Academy of Sciences, Beijing 100085, China \\ ${ }^{\ddagger}$ Institute of Environment and Health, Jianghan University, Hubei Province, Wuhan 430056, China \\ ${ }^{\S}$ Chemical Metrology and Analytical Science Division, National Institute of Metrology, P. R. China, Beijing 100029
}

\section{Supporting Information}

ABSTRACT: Hollow fiber supported liquid membrane (HFSLM) extraction was coupled with ICP-MS for speciation analysis of labile $\mathrm{Ag}(\mathrm{I})$ and total $\mathrm{Ag}(\mathrm{I})$ in dispersions of silver nanoparticles (AgNPs) and environmental waters. $\operatorname{Ag}(\mathrm{I})$ in aqueous samples was extracted into the HFSLM of $5 \%(\mathrm{~m} / \mathrm{v})$ tri- $n$-octylphosphine oxide in $n$ undecane, and stripped in the acceptor of $10 \mathrm{mM} \mathrm{Na} \mathrm{S}_{2} \mathrm{O}_{3}$ and $1 \mathrm{mM} \mathrm{Cu}\left(\mathrm{NO}_{3}\right)_{2}$ prepared in $5 \mathrm{mM} \mathrm{NaH} \mathrm{PO}_{4}-\mathrm{Na}_{2} \mathrm{HPO}_{4}$ buffer ( $\mathrm{pH} 7.5$ ). Negligible depletion and exhaustive extraction were conducted under static and $250 \mathrm{rpm}$ shaking to extract the labile $\mathrm{Ag}(\mathrm{I})$ and total $\mathrm{Ag}(\mathrm{I})$, respectively. The extraction equilibration was reached in $8 \mathrm{~h}$ for both extraction modes. The extraction efficiency and detection limit were $(2.97 \pm$ $0.25) \%$ and $0.1 \mu \mathrm{g} / \mathrm{L}$ for labile $\mathrm{Ag}(\mathrm{I})$, and $(82.3 \pm 2.0) \%$ and $0.5 \mu \mathrm{g} / \mathrm{L}$ for total $\mathrm{Ag}(\mathrm{I})$ detection, respectively. The proposed method was applied to determine labile $\mathrm{Ag}(\mathrm{I})$ and total $\mathrm{Ag}(\mathrm{I})$ in different sized AgNP dispersions and real environmental waters, with spiked recoveries of total $\mathrm{Ag}(\mathrm{I})$ in the range of $74.0-98.1 \%$. With the capability of distinguishing labile and total $\mathrm{Ag}(\mathrm{I})$, our method offers a new approach for evaluating

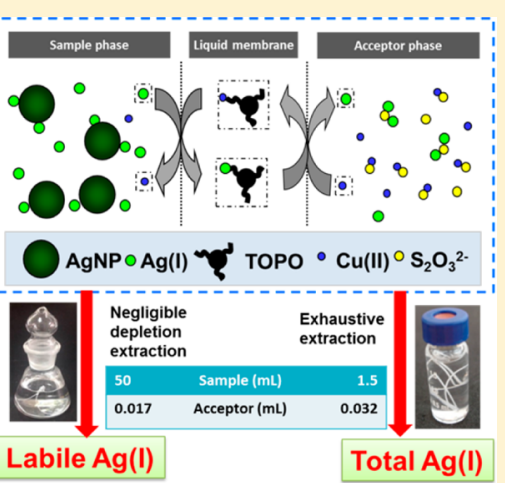
the bioavailability and understanding the fate and toxicity of AgNPs in aquatic systems.

$\mathrm{E}$ ngineered metal/metal oxide nanomaterials are widely used in various areas and have been detected in the environment. ${ }^{1-5}$ Due to their oxidation and dissolution, metal/ metal oxide nanomaterials in environments coexist with metal ions that may be present in the form of free ions, complexes with the capping agents or ligands in the matrixes, and

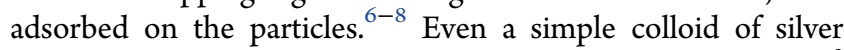
nanoparticles (AgNPs) consists of three silver forms: $\mathrm{Ag}^{0}$ nanoparticles, soluble $\mathrm{Ag}^{+}$and surface-adsorbed $\mathrm{Ag}^{+}$.

While it is generally believed that the free/labile metal ions are responsible for the toxicity of metals in environment, and the metal ions associated with matrix (such as particles and nature organic matter) are not bioavailable, ${ }^{10-12}$ the case for nanoparticles is much more complicated because the particles could enter the cells by a Trojan-horse type mechanism. ${ }^{13,14}$ Therefore, determination of nanoparticulate and ionic species of metals in metal/metal oxide nanomaterial dispersions and environment waters is crucial for exploiting the applications, as well as for understanding and elucidating the environmental transportation, transformation, and toxicity properties of these materials. $^{15-18}$

Various techniques, such as centrifugation, ${ }^{19}$ centrifugal ultrafiltration, ${ }^{20}$ dialysis, ${ }^{21}$ ultrafiltration, ${ }^{22,23}$ cloud point extraction, $^{24-26}$ and magnetic solid phase extraction, ${ }^{27}$ were proposed for the separation and determination of nanoparticulate and ionic metals in various samples. Ion selective electrode (ISE) ${ }^{17,20,28-30}$ was adopted for measuring the free metal ions in nanomaterials. While the ISE method is quick and low-cost, it has limited sensitivity and reproducibility for nanomaterial samples. Moreover, this technique suffered from the lack of proper electrodes for some target metal ions. Although diffusive gradients in thin films (DGT) was used to measure labile $\operatorname{Ag}(\mathrm{I}),{ }^{20}$ it can only distinguish the metal ions and relatively large nanoparticles, as small nanoparticles are reported to accumulate in the DGT device. ${ }^{31}$ Inductively coupled plasma mass spectrometry (ICP-MS) was performed in single-particle mode, but it can only distinguish metal ions from nanoparticles of over $20 \mathrm{~nm} .{ }^{32-34}$ ICP-MS was also coupled with field-flow fractionation $(\mathrm{FFF})^{35-38}$ for selective determination of AgNPs in the presence of $\mathrm{Ag}^{+}$, and coupled with reversed-phase liquid chromatography (LC) $)^{39,40}$ or capillary electrophoresis $(\mathrm{CE})^{41}$ for speciation test of AgNPs and dissolved monovalent silver $(\mathrm{Ag}(\mathrm{I}))$, which includes $\mathrm{Ag}^{+}$and its

Received: June 16, 2015

Revised: October 5, 2015

Accepted: November 18, 2015

Published: November 18, 2015 
complexes. However, these methods are incapable of distinguishing labile $\operatorname{Ag}(\mathrm{I})$ and total $\operatorname{Ag}(\mathrm{I})$.

Supported liquid membrane (SLM), also named as permeation liquid membrane (PLM), has been demonstrated an advantageous technique to evaluate the bioavailability/ toxicity of chemicals including metals ${ }^{12,42-48}$ and organic compounds. ${ }^{49,50}$ In SLM, target chemicals were extracted into a liquid membrane, a hydrophobic organic solvent or a mixture of hydrophobic organic solvents/carrier supported on a microporous membrane (planar or hollow fiber), and reextracted to the strip solution. It has been shown that either free metal ion concentration or the total concentration of labile complexes can be measured by tuning the extraction conditions. ${ }^{44}$ This advanced separation technique combines selective extraction, re-extraction and preconcentration of the target species into one step, thus provides high sensitivity and selectivity for speciation analysis. Additionally, it mimics somehow the biological membrane in uptake of chemicals and had been adopted in evaluation of the bioavailability/ toxicity of chemicals especially metal species. ${ }^{12,44-49}$ However, SLM has neither been exploited in the speciation analysis nor the bioavailability/toxicity evaluation of nanomaterials.

Herein, we report the development of a novel analytical method for the determination of labile and total $\mathrm{Ag}(\mathrm{I})$, respectively, by coupling hollow fiber based SLM (HFSLM) with ICP-MS. Labile $\mathrm{Ag}(\mathrm{I})$ and total $\mathrm{Ag}(\mathrm{I})$ in dispersions of AgNPs and water samples were extracted by the negligible depletion extraction and the exhaustive extraction mode, respectively. The established methods were applied to analyze labile $\mathrm{Ag}(\mathrm{I})$ and total $\mathrm{Ag}(\mathrm{I})$ in various sized AgNPs dispersions and environmental waters.

\section{EXPERIMENTAL SECTION}

Chemicals and Materials. Tri- $n$-octylphosphine oxide (TOPO, 98\%) and $n$-undecane (99\%) were purchased from Alfa Aesar (Massachusetts). Silver nitrate, sodium thiosulfate, copper nitrate, disodium hydrogen phosphate dodecahydrate, and sodium dihydrogen phosphate dehydrate were analyticalreagent grade or above and obtained from Sinopharm Chemical Reagent Beijing (Beijing, China). Nitric acid (65\%) was obtained from Merck (Darmstadt, Germany). Stock solutions of $\mathrm{Ag}^{+}(100 \mathrm{mg} / \mathrm{L})$ and $\mathrm{Cu}^{2+}(0.1 \mathrm{~mol} / \mathrm{L})$ were prepared by dissolution of $\mathrm{AgNO}_{3}$ and $\mathrm{Cu}\left(\mathrm{NO}_{3}\right)_{2}$ in $0.2 \mathrm{M} \mathrm{HNO}_{3}$, respectively. The 50/280 Accurel PP polypropylene hollow fiber tubing ( $50 \mu \mathrm{m}$ wall thickness, $280 \mu \mathrm{m}$ inner diameter, and $0.1 \mu \mathrm{m}$ pore size) was bought from Membrana $\mathrm{GmbH}$ (Wuppertal, Germany). Ultrapurified water (EASY-pure LF, Barnstead International, Dubuque, IA) was used throughout the experiments.

Preparation and Characterization of AgNPs. Polyvinylpyrrolidone (PVP) capped AgNP (AgNP-1) with particle size of $37.5 \pm 6.0 \mathrm{~nm}$ was synthesized by reduction of $\mathrm{AgNO}_{3}$ with sodium hypophosphite as described in our previous study, ${ }^{24}$ while PVP capped AgNPs with particle size of $16.2 \pm$ $5.4 \mathrm{~nm}$ (AgNP-2) and $48.9 \pm 12.1 \mathrm{~nm}$ (AgNP-3) were synthesized by reduction of $\mathrm{AgNO}_{3}$ with hydroxylamine hydrochloride. Another PVP coated AgNPs (AgNP-5) with particle size of $9.12 \pm 2.22 \mathrm{~nm}$ and the glutathione protected silver nanoclusters about $1 \mathrm{~nm}$ (AgNP-6) were synthesized by reduction of $\mathrm{AgNO}_{3}$ with sodium tetraethylborate as described as our previous work. ${ }^{17,40}$ Details on their synthesis are shown in Supporting Information (SI). Stock suspensions of the four PVP capped AgNPs were prepared by redispersion of the PVP capped AgNPs with water. AgNP-4 was obtained by soaking a piece of wound dressings (ACTICOAT Flex, Smith \& Nephew, Canada), which contains AgNPs (Silcryst nanocrystalline silver), with water for $20 \mathrm{~h}$. TEM images and size distribution of AgNPs except for AgNP-1 are shown in SI Figures S1 and S2.

The absorbance spectra of AgNPs were recorded with a multimode microplate spectrophotometer (Varioscan Flash, Thermo). Transmission electron microscope (TEM) was carried out with H-7500 (Hitachi, Japan) at $80 \mathrm{kV}$, while field emission scanning electron microscopy (FESEM) was performed with Su-8020 (Hitachi, Japan) coupled with energy dispersive spectrometer (EDS, Oxford, UK) at $15 \mathrm{kV}$. TEM samples were prepared by loading $5 \mu \mathrm{L}$ aliquots of the aqueous sample onto carbon-coated grid sample holders. The size distribution of the nanoparticles was estimated using Image-Pro plus software and Gaussian fitting. The particles counted from multipicture were over 200 for AgNP-2, AgNP-3, and AgNP-5, and over 100 for AgNP-4. For FESEM observation, the hollow fiber after extraction was treated with liquid nitrogen and fractured immediately. All the AgNPs stock dispersions were kept in the dark and quantified by ICP-MS. The free $\mathrm{Ag}^{+}$in the samples was determined by ISE as described in our previous study. $^{24}$

Water Sample Collection. The lake water was collected from Peking University, and the river water was collected upstream of Yongding River in the northwest of Beijing (China). Municipal sewage effluent was collected at Qinghe wastewater treatment plant (WWTP) in the west part of Beijing. All the water samples were filtered with $0.22 \mu \mathrm{m}$ membrane before analysis.

HFSLM Extraction and ICP-MS Determination of $\mathbf{A g}(\mathrm{I})$. For HFSLM extraction, $5 \%(\mathrm{~m} / \mathrm{v})$ TOPO dissolved in $n$ undecane was used as liquid membrane, whereas $5 \mathrm{mM}$ $\mathrm{NaH}_{2} \mathrm{PO}_{4}-\mathrm{Na}_{2} \mathrm{HPO}_{4}$ buffer ( $\mathrm{pH}$ 7.5) containing $10 \mathrm{mM}$ $\mathrm{Na}_{2} \mathrm{~S}_{2} \mathrm{O}_{3}$ and $1 \mathrm{mM} \mathrm{Cu}\left(\mathrm{NO}_{3}\right)_{2}$ as acceptor. Hollow fiber membranes were manually cut into pieces of 30 and $60 \mathrm{~cm}$, and looped for preparing the extraction device for the negligible depletion extraction and exhaustive extraction mode, respectively, with procedures modified from our previous study. ${ }^{49,51}$ Briefly, into the lumen of the hollow fiber was filled with the acceptor by using a syringe, and then the hollow fiber membrane was dipped into the $5 \%(\mathrm{~m} / \mathrm{v})$ TOPO in $n$ undecane for a $2 \mathrm{~min}$ to form the liquid membrane in the micropores of the membrane wall. The two ends of the hollow fiber membrane were folded and sealed with a strip of aluminum foil. After washing away the surplus membrane liquid on the surface of the fiber with water, the HFSLM devices were ready for extraction.

The labile $\operatorname{Ag}(\mathrm{I})$ was extracted by immersing the $30 \mathrm{~cm}$ HFSLM device into $50 \mathrm{~mL}$ of sample solution placed in a 50 $\mathrm{mL}$ flask and keep static for $8 \mathrm{~h}$, while the total $\mathrm{Ag}(\mathrm{I})$ was extracted by immersing the $60 \mathrm{~cm}$ HFSLM device into the 1.5 $\mathrm{mL}$ of sample solution placed in a $2.0 \mathrm{~mL}$ vial, which was then shaked at $250 \mathrm{rpm}$ for $8 \mathrm{~h}$. After that, the acceptor phase in the hollow fiber was flushed into a clean sample vial, and diluted to 0.5 to $2.0 \mathrm{~mL}$ based on the concentration with $2 \%(\mathrm{v} / \mathrm{v}) \mathrm{HNO}_{3}$ for ICP-MS analysis. Based on the weight of the collected acceptor, the volume ratio of sample to acceptor $(\mathrm{Vs} / \mathrm{Va})$ was $(50 \mathrm{~mL}: 0.017 \mathrm{~mL})$ and $(1.5 \mathrm{~mL}: 0.032 \mathrm{~mL})$ in the extraction of labile $\mathrm{Ag}(\mathrm{I})$ and total $\mathrm{Ag}(\mathrm{I})$, respectively. Certified reference material $(1000 \mathrm{mg} / \mathrm{L} \mathrm{Ag}$, GBW08610, National Institute of 
Metrology, China) was diluted with $3 \%$ (v/v) $\mathrm{HNO}_{3}$ for preparing calibration solutions.

The ICP-MS determination was mainly conducted by using the 7500ce ICP-MS (Agilent Technologies, Palo Alto, CA) equipped with a glass nebulizer at a flow rate of $0.4 \mathrm{~mL} / \mathrm{min}$. However, a 7700x ICP-MS (Agilent) equipped with a PFA nebulizer with a flow rate of $0.1 \mathrm{~mL} / \mathrm{min}$ when high sensitivity was required.

\section{RESULTS AND DISCUSSION}

Mechanisms of Extracting Labile and Total Dissolved Ag(I) by HFSLM. In this study, TOPO was adopted as carrier because it is stable and commonly used as carrier in SLM, while a mixture of $\mathrm{Cu}\left(\mathrm{NO}_{3}\right)_{2}$ and $\mathrm{Na}_{2} \mathrm{~S}_{2} \mathrm{O}_{3}$ was employed as acceptor as the complex constant of $\mathrm{S}_{2} \mathrm{O}_{3}{ }^{2-}$ with $\mathrm{Cu}^{2+}$ is lower than that with $\mathrm{Ag}^{+}$but higher than that with other metal complexes, and therefore provides high extraction selectivity for $\mathrm{Ag}(\mathrm{I})$. Figure 1

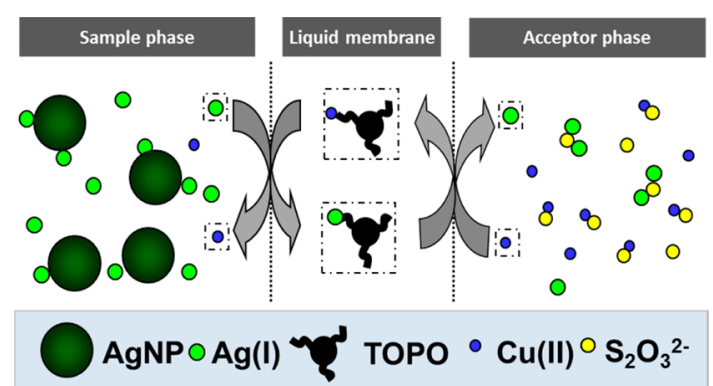

Figure 1. Mechanism diagram of HFSLM extraction of $\mathrm{Ag}(\mathrm{I})$.

shows the principle for HFSLM extraction of dissolved $\mathrm{Ag}(\mathrm{I})$, including $\mathrm{Ag}^{+}$and its various complexes. Briefly, the transport of dissolved $\mathrm{Ag}(\mathrm{I})$ in HFSLM occurs by (i) $\mathrm{Ag}^{+}$and anion $\mathrm{X}^{-}$, which can be $\mathrm{OH}^{-}, \mathrm{Cl}^{-}$or coating agents of AgNPs that are able to associate with $\mathrm{Ag}^{+}$to form complexes with lower complex constants than that of $\left[\mathrm{Ag}_{2} \mathrm{~S}_{2} \mathrm{O}_{3}\right]$, in the sample solution diffuses to the donor-membrane interface and associates with TOPO to form complex [AgX'mTOPO] through solvating reaction; (ii) $[\mathrm{AgX} \cdot \mathrm{mTOPO}]$ then diffuses through the membrane toward the membrane-acceptor interface where exchange reaction with $\mathrm{CuS}_{2} \mathrm{O}_{3}$ occurs to form new complexes $\left[\mathrm{Ag}_{2} \mathrm{~S}_{2} \mathrm{O}_{3}\right]$; (iii) $\left[\mathrm{Ag}_{2} \mathrm{~S}_{2} \mathrm{O}_{3}\right]$ is trapped in the acceptor due to its higher complex constant than $\mathrm{AgX}$, and TOPO diffuses back to the donor-membrane interface for repeating the processes as depicted by eqs 1 and $2,{ }^{48}$

$$
\mathrm{Ag}^{+}(\mathrm{aq})+\mathrm{X}^{-}(\mathrm{aq})+\mathrm{mTOPO}(\mathrm{org})=[\mathrm{AgX} \cdot \mathrm{mTOPO}](\text { org })
$$

$$
\begin{aligned}
& 2[\mathrm{AgX} \cdot \mathrm{mTOPO}](\mathrm{org})+\mathrm{CuS}_{2} \mathrm{O}_{3}(\mathrm{aq})=\left[\mathrm{Ag}_{2} \mathrm{~S}_{2} \mathrm{O}_{3}\right](\mathrm{aq}) \\
& +2 \mathrm{X}^{-}(\mathrm{aq})+\mathrm{Cu}^{2+}(\mathrm{aq})+2 \mathrm{mTOPO}(\mathrm{org})
\end{aligned}
$$

in which (aq) represents the aqueous phase, and (org) represents the organic liquid membrane phase. This mechanism was verified by the molar ratio of $\mathrm{Ag}$ in the acceptor to $\mathrm{Cu}$ in donor phase at extraction equilibrium $(8 \mathrm{~h})$, which was determined to be 1.8:1 (agreed with the theoretical value of 2:1) by using ICP-MS.

Two extraction modes of HFSLM, ${ }^{52}$ the negligible depletion extraction $^{49}$ and the exhaustive extraction, ${ }^{51}$ were coupled to ICP-MS for analyzing the labile and the total $\mathrm{Ag}(\mathrm{I})$ content, respectively. In the negligible depletion HFSLM, in order to avoid disturbing the equilibrium between the labile $\mathrm{Ag}(\mathrm{I})$ and other forms of dissolved $\mathrm{Ag}(\mathrm{I})$ such as nanoparticle-adsorbed $\operatorname{Ag}(\mathrm{I})$, the extracted $\operatorname{Ag}(\mathrm{I})$ was controlled to below $5 \%$ of the total $\operatorname{Ag}(\mathrm{I})$ by using large phase volume ratio of donor to acceptor and low enrichment factor of $\mathrm{Ag}(\mathrm{I})$ in the acceptor. For sensing the total $\mathrm{Ag}(\mathrm{I})$, the exhaustive extraction mode of HFSLM was conducted by using low volume ratio of donor to acceptor and long extraction time, which helps the complete transportation of $\mathrm{Ag}(\mathrm{I})$ from donor into the acceptor. The enrichment was calculated by ratio of $\mathrm{Ag}(\mathrm{I})$ concentration in the acceptor after extraction to initial $\mathrm{Ag}(\mathrm{I})$ concentration in the sample.

Optimization of the Extraction Conditions. Parameters that usually influence the extraction efficiency were optimized with $20 \mu \mathrm{g} / \mathrm{L} \mathrm{Ag}(\mathrm{I})\left(\mathrm{AgNO}_{3}\right)$ standard solutions, and the enrichment factor of $\mathrm{Ag}(\mathrm{I})$ (the ratio of final $\mathrm{Ag}(\mathrm{I}$ ) concentration in the acceptor to the initial $\mathrm{Ag}(\mathrm{I})$ concentration in the sample) was used to evaluate the extraction efficiency.

Membrane Liquid. Although both dihexyl ether and nundecane were widely used as organic membrane liquid, $n$ undecane was adopted in this study as dihexyl ether might interact with AgNPs through the $\mathrm{Ag}-\mathrm{O}$ interaction. While bis(2-ethylhexyl) phosphate (DEPHA) and TOPO are usually used as carrier in SLM of metal ions, our previous success in SLM of $\mathrm{Hg}(\mathrm{II})$ with $\mathrm{TOPO}^{48}$ encouraged us to use TOPO in this study. Experiments showed that the enrichment factor of $\mathrm{Ag}(\mathrm{I})$ increased sharply with TOPO concentration in the range of $1-4 \%(\mathrm{~m} / \mathrm{v})$ and then increased very slowly (SI Figure S3), thus $5 \%(\mathrm{~m} / \mathrm{v})$ TOPO in $n$-undecane was used as the optimum liquid membrane.

Acceptor Solution. The enrichment factor of $\mathrm{Ag}(\mathrm{I})$ increased with $\mathrm{Na}_{2} \mathrm{~S}_{2} \mathrm{O}_{3}$ concentration up to $10 \mathrm{mM}$ and then decreased with the further increase of $\mathrm{Na}_{2} \mathrm{~S}_{2} \mathrm{O}_{3}$ concentration (SI Figure S4). The reduced enrichment factor of $\mathrm{Ag}(\mathrm{I})$ at high $\mathrm{Na}_{2} \mathrm{~S}_{2} \mathrm{O}_{3}$ concentration might be ascribed to the salt out effect, which reduced the partitioning of $\mathrm{Ag}_{2} \mathrm{~S}_{2} \mathrm{O}_{3}$ from the liquid membrane phase to the acceptor phase. The $\mathrm{Cu}^{2+}$ concentration in the acceptor was optimized from 0.02 to $2 \mathrm{mM}$, and result showed that the enrichment factor of $\mathrm{Ag}(\mathrm{I})$ increased with $\mathrm{Cu}^{2+}$ concentration up to $0.2 \mathrm{mM}$ and then remained constant until $2 \mathrm{mM}$ (SI Figure S5). The acceptor $\mathrm{pH}$ was optimized in the range of 5.0-9.0 with $5 \mathrm{mM}$ phosphate buffer, and it was found that the maximum enrichment factor was obtained at $\mathrm{pH} 7.5$ (SI Figure S6). Consequently, $10 \mathrm{mM}$ $\mathrm{Na}_{2} \mathrm{~S}_{2} \mathrm{O}_{3}$ and $1 \mathrm{mM} \mathrm{Cu}\left(\mathrm{NO}_{3}\right)_{2}$ prepared in $5 \mathrm{mM} \mathrm{Na}_{2} \mathrm{HPO}_{4}-$ $\mathrm{NaH}_{2} \mathrm{PO}_{4}$ buffer ( $\mathrm{pH} 7.5$ ) was adopted as acceptor.

Shaking Rate. Agitation such as shaking improves the diffusion rate and thus the extraction efficiency in cases that diffusion of analytes through the aqueous diffusion layer is the rate limiting process of SLM, but has no effect in cases that the diffusion of metal-carrier complex across the membrane is the rate-limiting step. ${ }^{53}$ In the extraction of labile $\mathrm{Ag}(\mathrm{I})$, enhancement of the extraction was not observed by increasing the shaking rate from 50 to $200 \mathrm{rpm}$ (SI Figure S7), thus diffusion through the membrane is the rate limiting process and static extraction was adopted. While for the exhaustive HFSLM extraction of total $\mathrm{Ag}(\mathrm{I})$, the effect of shaking rate was evaluated in the range of $0-250 \mathrm{rpm}$. Results (SI Figure S8) showed that the $250 \mathrm{rpm}$ provided the highest extraction efficiency and was adopted in this study. With the progress of exhaustive extraction, depletion of $\mathrm{Ag}(\mathrm{I})$ in the aqueous phase occurs and diffusion of $\operatorname{Ag}(\mathrm{I})$ through the aqueous diffusion layer becomes the rate limiting step. Therefore, high shaking rate can enhance the extraction efficiency. 

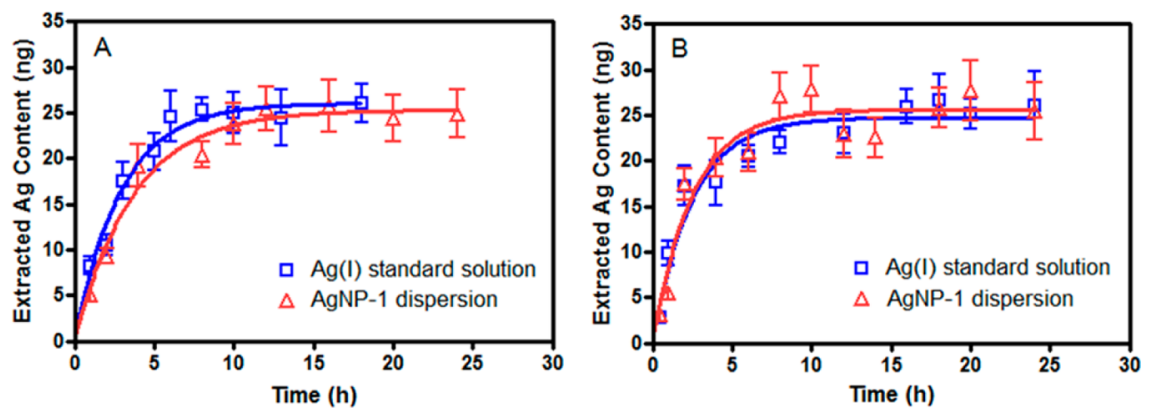

Figure 2. Effects of time on the extraction of labile $\mathrm{Ag}(\mathrm{I})$ (A) and total $\mathrm{Ag}$ (I) (B) in $\mathrm{AgNO}_{3}$ standard solution (20 $\left.\mu \mathrm{g} / \mathrm{L} \mathrm{Ag}\right)$ or AgNP-1 dispersion $(1 \mathrm{mg} / \mathrm{L} \mathrm{Ag})$. The acceptor solution contains $10 \mathrm{mM} \mathrm{Na}_{2} \mathrm{~S}_{2} \mathrm{O}_{3}, 1 \mathrm{mM} \mathrm{Cu}{ }^{2+}$, and $5 \mathrm{mM} \mathrm{Na}_{2} \mathrm{HPO}_{4}-\mathrm{NaH}_{2} \mathrm{PO}_{4}$ buffer (pH 7.5); the liquid membrane is $5 \%(\mathrm{~m} / \mathrm{v})$ TOPO in $n$-undecane. The sample volume and length of HFSLM device are $50 \mathrm{~mL}$ and $30 \mathrm{~cm}$ for extraction of labile $\mathrm{Ag}(\mathrm{I})$, and $1.5 \mathrm{~mL}$ and $60 \mathrm{~cm}$ in extraction of total $\mathrm{Ag}(\mathrm{I})$, respectively. Each point represents the mean values \pm standard deviation for three replicates. Note the extracted $\mathrm{Ag}$ amount instead of enrichment factor was used as $Y$-axis, as the enrichment factor cannot be calculated for the lack of exact concentration of labile and total $\mathrm{Ag}(\mathrm{I})$ concentration in the AgNP dispersions.

Extraction Time. Preliminary studies (3 h extraction) indicated that, for samples in the studied range of $\mathrm{pH}$ 6.0-8.0, the lowest extraction efficiency was observed at $\mathrm{pH}$ 6.0-7.0. Therefore, $\operatorname{Ag}(\mathrm{I})$ standard solutions $(\sim 20 \mu \mathrm{g} / \mathrm{L})$ and AgNP dispersions (1000 $\mu \mathrm{g} / \mathrm{L}$ AgNPs) with the same $\mathrm{pH}$ (6.5) and comparable $\mathrm{Ag}(\mathrm{I})$ concentration were used to test the equilibration time under the above optimized conditions. Figure 2 shows the profiles of the uptake of $\mathrm{Ag}(\mathrm{I})$ in the acceptor which indicate that for both the labile and total $\mathrm{Ag}(\mathrm{I})$, the extraction reached equilibration in $8 \mathrm{~h}$. Although the highest enrichment factor and thus method sensitivity can be obtained by using equilibrium extraction, the relatively long equilibration time $(8 \mathrm{~h})$ might give rise to artifacts due to the release of $\mathrm{Ag}^{+}$from $\mathrm{Ag}$ nanoparticles during the extraction process. While kinetic extraction with short extraction time (e.g., $15 \mathrm{~min}$ ) can avoid the artifacts, it provides low enrichment factor and thus high detection limit. More importantly, strict control of extraction conditions is required in kinetic extraction, which is more complicated to handle than equilibrium extraction. ${ }^{49}$ Experiments showed that for the samples in this study, the release of $\mathrm{Ag}^{+}$from $\mathrm{Ag}$ nanoparticles during the extraction is limited, thus equilibrium extraction (8 h) was employed as optimum in the following studies to obtain high enrichment factor. For samples that extended extraction might vary the $\mathrm{Ag}^{+}$contents, kinetic extraction with strictly controlled extraction conditions is recommended.

Sample $\mathrm{pH}$. Under the optimum extraction time, the effect of sample $\mathrm{pH}$ on the enrichment factor of labile $\mathrm{Ag}(\mathrm{I})$ in a 20 $\mu \mathrm{g} / \mathrm{L} \mathrm{Ag}(\mathrm{I})$ solution was tested by adjusting the sample $\mathrm{pH}$ with $5 \mathrm{mM} \mathrm{Na} 2 \mathrm{HPO}_{4}-\mathrm{NaH}_{2} \mathrm{PO}_{4}$ buffer. As shown in Figure 3, the enrichment factor kept constant in the entire studied range of $\mathrm{pH}$ 5.5-9.0, suggesting that this proposed method extracts labile $\mathrm{Ag}(\mathrm{I})$ rather than only free $\mathrm{Ag}^{+}$. As free $\mathrm{Ag}^{+}$is expected to varied with sample $\mathrm{pH}$ values, the enrichment factor should vary with $\mathrm{pH}$ variation if only free $\mathrm{Ag}^{+}$is extracted. The result also indicates that in determination of labile $\mathrm{Ag}(\mathrm{I})$ by this proposed method, samples with $\mathrm{pH}$ 5.5-9.0 can be calibrated with a common calibration curve prepared with standard solutions at $\mathrm{pH}$ 6.5.

Method Selectivity Toward Ag(I). In this study, the method selectivity to $\mathrm{Ag}(\mathrm{I})$ relies on its selective extraction of $\mathrm{Ag}(\mathrm{I})$ from AgNP dispersions, that is, the AgNPs should not be extracted. To test if the AgNPs were transported through the liquid membrane and trapped into the acceptor, $20 \mathrm{mg} / \mathrm{L}$ AgNP-1 and $10 \mathrm{mg} / \mathrm{L}$ AgNP-5 dispersions were extracted,

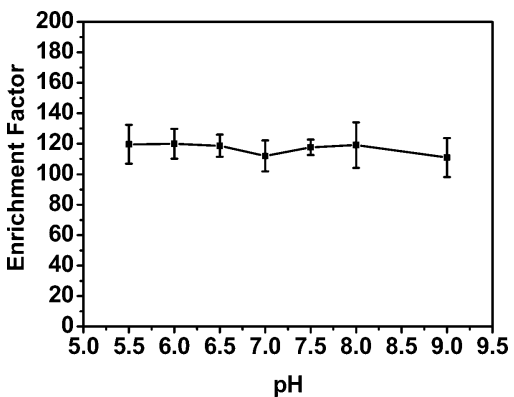

Figure 3. Effect of sample $\mathrm{pH}$ on the extraction of $\mathrm{Ag}(\mathrm{I})$. The $50 \mathrm{~mL}$ of $\mathrm{AgNO}_{3}$ solutions $(20 \mu \mathrm{g} / \mathrm{L} \mathrm{Ag})$ was extracted with $10 \mathrm{mM} \mathrm{Na}_{2} \mathrm{~S}_{2} \mathrm{O}_{3}$ and $1 \mathrm{mM} \mathrm{Cu}^{2+}$ filled in the $30 \mathrm{~cm}$ HFSLM device for $8 \mathrm{~h}$. The liquid membrane is $5 \%(\mathrm{~m} / \mathrm{v})$ TOPO in $n$-undecane. Each point represents the mean values \pm standard deviation for three replicates.

respectively, under the above optimized conditions for total $\mathrm{Ag}(\mathrm{I})$. Figure 4E shows the respective UV-vis spectra of the sample before and after extraction, and the acceptor after extraction. The absence of the characteristic maximum peak absorbance of AgNPs $(\sim 410 \mathrm{~nm})$ in the acceptor indicates that the AgNPs were not extracted into the acceptor. Although the hollow fiber membrane has micropores of $100 \mathrm{~nm}$, the AgNPs are not able to transfer through the membrane due to the fact that the membrane pores are filled with membrane liquid into which the AgNPs are unable to distributed. The slight reduction of peak absorbance $(412 \mathrm{~nm})$ of the sample after extraction (Figure 4E) suggests that a small part of the AgNPs were adsorbed on the surface of the container or the hollow fiber membrane. To verify these results, we detected the acceptor solution with TEM, and the cross section and the surface (both inner and outer) of the hollow fiber wall with FESEM-EDS after extraction (Figure 4A-D). The absence of nanoparticles in the TEM image of the acceptor (data not shown) again verified that AgNPs were not extracted. Although Ag signal was observed in the EDS of the outer wall of the hollow fiber, the absence of Ag signal in the EDS of the inner wall and the cross section of the hollow fiber indicates that the AgNPs cannot diffuse into the membrane (Figure 4D). The presence of intense signal of $\mathrm{Na}, \mathrm{P}$, and $\mathrm{S}$ in EDS stemmed from TOPO, $\mathrm{Na}_{2} \mathrm{~S}_{2} \mathrm{O}_{3}$ and phosphate buffer. In order to further verify that small sized $(<10 \mathrm{~nm})$ AgNPs were not extracted into acceptor phase, the AgNPs and $\mathrm{Ag}(\mathrm{I})$ in the sample solutions (9.12 nm AgNP-5 and $1 \mathrm{~nm}$ AgNP-6, $10 \mathrm{mg} / \mathrm{L}$ ) before 


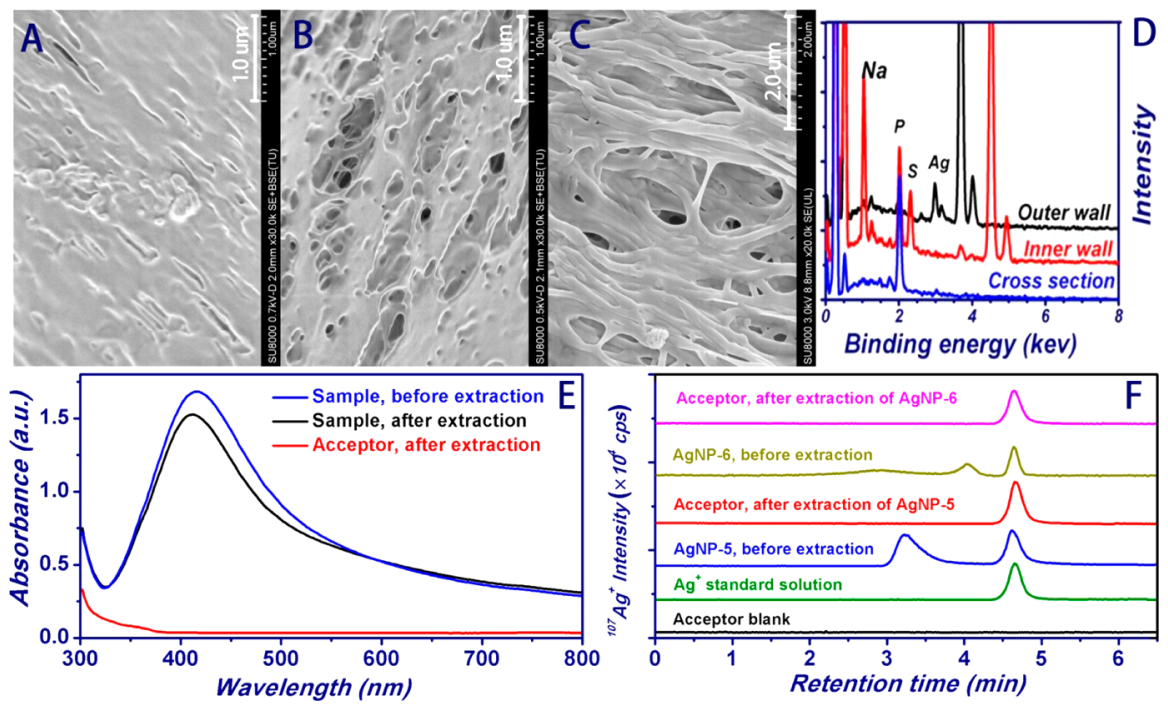

Figure 4. Evidence for excluding the coextraction of AgNPs in proposed HFSLM procedures. The extraction was conducted under the optimized conditions for extracting the total $\mathrm{Ag}(\mathrm{I})$ in $20 \mathrm{mg} / \mathrm{L}$ and $10 \mathrm{mg} / \mathrm{L}$ of AgNPs. (E) The UV-vis spectra of sample (20 mg/L AgNP standard) before and after extraction, and the acceptor after extraction; (A, B, C) FESEM images of the outer wall (A), inner wall (B) and cross section (C) and their corresponding EDS spectra (D) of hollow fiber after extraction. (F) Chromatograms of Ag (I) standard, acceptor blank, and the sample phase before extraction and the acceptor phase after extraction of $10 \mathrm{mg} / \mathrm{L}$ AgNP-5 $(9.12 \pm 5.4)$ and AgNP-6 $(\sim 1 \mathrm{~nm})$. The chromatographic separation was performed with an amino column of 500 Å poresize, and a $0.7 \mathrm{~mL} / \mathrm{min}$ mobile phase containing $0.1 \%(\mathrm{v} / \mathrm{v}) \mathrm{FL}-70$ and $2 \mathrm{mM} \mathrm{Na}_{2} \mathrm{~S}_{2} \mathrm{O}_{3}$.

extraction and the acceptor after extraction were determined, respectively, with the HPLC-ICPMS method reported in our previous work. ${ }^{40}$ This method is very sensitive and can detect AgNPs at sub $\mu$ g/L level. Results shown in Figure 4F indicated that while the AgNP peaks were detected in the sample solutions, no AgNP peaks were detected in the acceptor after extraction, demonstrating small AgNPs even silver clusters were not extracted. Combining all the above results, it is safe to say that AgNPs were not extracted into the acceptor, and silver content in the acceptor determined by ICP-MS stems from the $\operatorname{Ag}(\mathrm{I})$ only.

Analytical Performance. Table 1 shows the analytical performance including linear range, calibration curve, correla-

Table 1. Analytical Performance of the Proposed Methods

\begin{tabular}{lll} 
& \multicolumn{1}{c}{ labile $\mathrm{Ag}(\mathrm{I})$} & \multicolumn{1}{c}{ total $\mathrm{Ag}(\mathrm{I})$} \\
linear range $(\mu \mathrm{g} / \mathrm{L})$ & $0.3-100$ & $1.5-100$ \\
calibration equation & $\mathrm{y}=80.54 \mathrm{x}+92.71$ & $\mathrm{y}=0.9130 \mathrm{x}+0.2779$ \\
$R^{2}$ & 0.996 & 0.999 \\
$\mathrm{RSD}(\%, n=6)$ & 12 & 2.4 \\
$\mathrm{LOD}(\mu \mathrm{g} / \mathrm{L})$ & 0.1 & 0.5 \\
extraction efficiency $(\%)$ & $2.97 \pm 0.25$ & $82.3 \pm 2.0$ \\
enrichment factor & $93.5 \pm 11.4$ & $26.4 \pm 0.9$ \\
\hline
\end{tabular}

tion coefficient $\left(r^{2}\right)$, relative standard deviation (RSD), enrichment factor, limit of detection (LOD) and limit of quantification (LOQ). The linearity was tested by extracting 7 $\mathrm{AgNO}_{3}$ standard solutions containing 0, 2, 5, 10, 20, 50, and $100 \mu \mathrm{g} / \mathrm{L} \mathrm{Ag}$. The concentration of $\mathrm{Ag}(\mu \mathrm{g} / \mathrm{L})$ in donor phase was used as $x$ axis, while the $\operatorname{Ag}(\mathrm{I})$ concentration $(\mu \mathrm{g} / \mathrm{L})$ and total Ag mass (ng) in acceptor phase were used as $y$ axis for preparation of calibration curve of labile $\mathrm{Ag}(\mathrm{I})$ and total $\mathrm{Ag}(\mathrm{I})$, respectively. The extraction efficiency and reproducibility were determined by extracting $6 \mathrm{AgNO}_{3}$ standard solutions containing $20 \mu \mathrm{g} / \mathrm{L} \mathrm{Ag}$. The extraction efficiency of labile $\mathrm{Ag}(\mathrm{I})(2.97 \%)$ was below $5 \%$, indicating that it was a negligible depletion extraction and did not disturb the equilibrium between the various silver species in the sample. ${ }^{49}$ LOD and LOQ were calculated based on three times of baseline noise $(S$ / $N=3)$ and ten times of baseline noise $(S / N=10)$ for the determination of labile and total $\operatorname{Ag}(\mathrm{I})$, respectively. Thanks to the enrichment in the HFSLM procedure and the high sensitivity of ICP-MS, this proposed method shows low detection limits for labile and total $\mathrm{Ag}(\mathrm{I})$. It is noteworthy the method LOD and LOQ were strongly dependent on the instrument used. The data shown in Table 1 were obtained by using the 7500ce ICP-MS equipped with a glass nebulizer with a flow rate of $0.4 \mathrm{~mL} / \mathrm{min}$. However, by using the $7700 \mathrm{x}$ ICPMS equipped with a PFA nebulizer with a flow rate of $0.1 \mathrm{~mL} /$ min, the LOD for labile and total $\mathrm{Ag}(\mathrm{I})$ were decreased to 0.05 $\mu \mathrm{g} / \mathrm{L}$ and $0.2 \mu \mathrm{g} / \mathrm{L}$, respectively.

Sample Analysis. The labile and total $\mathrm{Ag}(\mathrm{I})$ in five AgNP dispersions were determined with results shown in Table 2. The total $\mathrm{Ag}(\mathrm{I})$ determination was verified by spiked recovery, which was in the range of $74.0-98.1 \%$ at spiking levels of 10 and $20 \mu \mathrm{g} / \mathrm{L}$, respectively (Table 2 ). The proposed method for labile $\operatorname{Ag}(\mathrm{I})$ determination cannot be verified by spiked recovery, as the species of $\mathrm{Ag}(\mathrm{I})$ might be modified after spiking. However, for all the samples, the fact that the values of labile $\mathrm{Ag}(\mathrm{I})$ located between the determined total $\mathrm{Ag}(\mathrm{I})$ and the free $\mathrm{Ag}^{+}$in sample dispersions determined by ISE indicates that the proposed method is reliable.

To further evaluate the applicability of the proposed method to real environmental waters, the labile and total $\operatorname{Ag}(\mathrm{I})$ were determined before and after adding AgNP-5 with the same concentration to lake water, river water and effluent of WWTP, respectively. Results shown in Table 3 indicated that the apparent extraction efficiency of total $\mathrm{Ag}(\mathrm{I})$ was between $74.2 \%$ and $93.1 \%$ for the three environmental water samples, demonstrating the common ions and DOC in environmental waters showed no effect on the extraction of total Ag (I) by the proposed HFSLM method.

In summary, the labile and total $\mathrm{Ag}(\mathrm{I})$ in $\mathrm{AgNP}$ dispersions and real environmental waters were determined by coupling 
Table 2. Labile $\operatorname{Ag}(\mathrm{I})$, Total $\mathrm{Ag}(\mathrm{I})$, Free $\mathrm{Ag}^{+}$and Spiked Recoveries of Total $\operatorname{Ag}(\mathrm{I})(\mathrm{Mean} \pm s, n=3)$ in $\operatorname{AgNP}$ Dispersions Determined by the Proposed HFSLM and ISE Method

\begin{tabular}{|c|c|c|c|c|c|c|c|}
\hline \multirow[b]{2}{*}{ sample } & \multirow[b]{2}{*}{ size } & \multirow[b]{2}{*}{ coating } & \multirow[b]{2}{*}{ free $\mathrm{Ag}^{+f}(\mu \mathrm{g} / \mathrm{L})$} & \multirow[b]{2}{*}{ labile $\operatorname{Ag}(\mathrm{I})(\mu \mathrm{g} / \mathrm{L})$} & \multicolumn{3}{|c|}{ total $\mathrm{Ag}(\mathrm{I})$} \\
\hline & & & & & spiked $(\mu \mathrm{g} / \mathrm{L})$ & detected $(\mu \mathrm{g} / \mathrm{L})$ & recovery $^{g}(\%)$ \\
\hline \multirow[t]{3}{*}{$\operatorname{AgNP}-1^{a}$} & $37.5 \pm 6.0$ & PVP & 18 & $26.6 \pm 1.4$ & 0 & $36.2 \pm 2.4$ & \\
\hline & & & & & 10 & $46.0 \pm 2.5$ & $98.0 \pm 10.9$ \\
\hline & & & & & 20 & $54.8 \pm 2.8$ & $93.2 \pm 7.5$ \\
\hline $\operatorname{AgNP}-2^{b}$ & $16.2 \pm 5.4$ & PVP & 25 & $38.8 \pm 4.0$ & 0 & $57.2 \pm 1.0$ & \\
\hline $\mathrm{AgNP}^{-} 3^{c}$ & $48.9 \pm 12.1$ & PVP & 20 & $31.4 \pm 1.0$ & 0 & $47.8 \pm 8.2$ & \\
\hline \multirow[t]{3}{*}{$\mathrm{AgNP}-4^{d}$} & $22.2 \pm 5.9$ & unknown & 17 & $16.2 \pm 0.4$ & 0 & $23.2 \pm 2.4$ & \\
\hline & & & & & 10 & $33.0 \pm 1.0$ & $98.1 \pm 6.1$ \\
\hline & & & & & 20 & $40.3 \pm 2.2$ & $85.3 \pm 8.5$ \\
\hline $\operatorname{AgNP}-5^{e}$ & $9.12 \pm 2.22$ & PVP & & $12.3 \pm 0.8$ & 0 & $15.9 \pm 0.6$ & \\
\hline
\end{tabular}

${ }^{a}$ Total silver concentration of $\sim 1.0 \mathrm{mg} / \mathrm{L} .{ }^{b, c}$ Before analysis, the samples were diluted 250 times to have a total silver concentration of $\sim 0.5 \mathrm{mg} / \mathrm{L}$. ${ }^{d} 0.0960 \mathrm{~g}$ of wound dressing was soaked with water $20 \mathrm{~h}$ and diluted 500 times to have a total silver concentration of $\sim 30.4 \mu \mathrm{g} / \mathrm{L} .{ }^{e} \mathrm{Total}$ silver

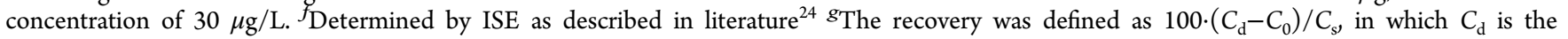
concentration determined in donor phase after spiking, $C_{0}$ is the initial concentration in donor phase, $C_{\mathrm{s}}$ is the spiked concentration.

Table 3. Labile and Total $\operatorname{Ag}(\mathrm{I})$ (Mean $\pm s, n=3$ ) in Environmental Waters Determined by the Proposed HFSLM Method

\begin{tabular}{|c|c|c|c|c|c|c|}
\hline sample & $\mathrm{pH}$ & $\begin{array}{l}\mathrm{DOC}^{a} \\
(\mathrm{mg} / \mathrm{L})\end{array}$ & spiked AgNP-5 $(\mu \mathrm{g} /$ & $\begin{array}{c}\text { detected labile } \operatorname{Ag}(\mathrm{I})(\mu \mathrm{g} / \\
\mathrm{L})\end{array}$ & $\begin{array}{l}\text { detected total } \operatorname{Ag}(\mathrm{I})(\mu \mathrm{g} / \\
\mathrm{L})\end{array}$ & $\begin{array}{c}\text { extraction efficiency of total } \mathrm{Ag}(\mathrm{I})^{c} \\
(\%)\end{array}$ \\
\hline \multirow[t]{2}{*}{ Lake water } & 8.5 & 13.6 & 0 & $\mathrm{ND}^{d}$ & $\mathrm{ND}$ & \\
\hline & & & 30 & $6.01 \pm 0.05$ & $14.8 \pm 0.6$ & 93.1 \\
\hline \multirow[t]{2}{*}{ River water } & 8.3 & 37.8 & 0 & ND & ND & \\
\hline & & & 30 & $6.92 \pm 0.33$ & $11.8 \pm 0.7$ & 74.2 \\
\hline \multirow[t]{2}{*}{ Effluent of WWTP } & 8.1 & 6.67 & 0 & $\mathrm{ND}$ & $\mathrm{ND}$ & \\
\hline & & & 30 & $5.66 \pm 0.26$ & $13.8 \pm 1.2$ & 86.8 \\
\hline
\end{tabular}

${ }^{a}$ Dissolved organic carbon. ${ }^{b}$ As total silver. ${ }^{c}$ Calculated based on the difference between the determined total $\mathrm{Ag}(\mathrm{I})$ in real water sample $\left(C_{\mathrm{rw}}\right)$ and in pure water $\left(\mathrm{C}_{\mathrm{pw}}\right)$ at the same spiked level of AgNP-5, by $100 \cdot\left(C_{\mathrm{pw}}-C_{\mathrm{pw}}\right) / C_{\mathrm{pw}}{ }^{d}$ Below the detection limit.

HFSLM with ICP-MS for the first time. While AgNPs was completely excluded by the liquid membrane, the $\operatorname{Ag}(\mathrm{I})$ in the sample were extracted into the liquid membrane with the help of TOPO carrier, and trapped in the acceptor through the exchange reaction with $\mathrm{CuS}_{2} \mathrm{O}_{3}$. The labile $\mathrm{Ag}(\mathrm{I})$ was sensed by using the negligible depletion extraction with large volume ratio of sample to acceptor, whereas the total $\mathrm{Ag}(\mathrm{I})$ was determined through exhaustive extraction with very small volume ratio of sample to acceptor. Given labile metal ions are more relevant to bioavailability and toxicity in comparison to total metal ions, this proposed method is expected to contribute in evaluating the bioavailability and toxicity of metal/metal oxide nanoparticles in aqueous systems.

\section{ASSOCIATED CONTENT}

\section{S Supporting Information}

The Supporting Information is available free of charge on the ACS Publications website at DOI: 10.1021/acs.est.5b02917.

Additional information as noted in the text (PDF)

\section{AUTHOR INFORMATION}

\section{Corresponding Author}

*Phone: +86-10-62849192; fax: +86-10-62849192; e-mail: jfliu@rcees.ac.cn.

\section{Notes}

The authors declare no competing financial interest.

\section{ACKNOWLEDGMENTS}

This work is supported by the Strategic Priority Research Program of the Chinese Academy of Sciences (XDB14020101), and the National Natural Science Foundation of China (21207124, 21227012, 21337004).

\section{REFERENCES}

(1) Kiser, M. A.; Westerhoff, P.; Benn, T.; Wang, Y.; Pérez-Rivera, J.; Hristovski, K. Titanium Nanomaterial Removal and Release from Wastewater Treatment Plants. Environ. Sci. Technol. 2009, 43 (17), 6757-6763.

(2) Luo, Z. X.; Wang, Z. H.; Li, Q. Z.; Pan, Q. K.; Yan, C. Z.; Liu, F. Spatial Distribution, Electron Microscopy Analysis of Titanium and Its Correlation to Heavy Metals: Occurrence and Sources of Titanium Nanomaterials in Surface Sediments from Xiamen Bay, China. J. Environ. Monit. 2011, 13 (4), 1046-1052.

(3) Prichard, H. M.; Fisher, P. C. Identification of Platinum and Palladium Particles Emitted from Vehicles and Dispersed into the Surface Environment. Environ. Sci. Technol. 2012, 46 (6), 3149-3154.

(4) Li, L.; Hartmann, G.; Döblinger, M.; Schuster, M. Quantification of Nanoscale Silver Particles Removal and Release from Municipal Wastewater Treatment Plants in Germany. Environ. Sci. Technol. 2013, 47 (13), 7317-7323.

(5) Gondikas, A. P.; Kammer, F. v. d.; Reed, R. B.; Wagner, S.; Ranville, J. F.; Hofmann, T. Release of $\mathrm{TiO}_{2}$ Nanoparticles from Sunscreens into Surface Waters: A One-Year Survey at the Old Danube Recreational Lake. Environ. Sci. Technol. 2014, 48 (10), 54155422.

(6) Lowry, G. V.; Gregory, K. B.; Apte, S. C.; Lead, J. R. Transformations of Nanomaterials in the Environment. Environ. Sci. Technol. 2012, 46 (13), 6893-6899. 
(7) Yu, S. J.; Yin, Y. G.; Liu, J. F. Silver Nanoparticles in the Environment. Environ. Sci.: Process Impacts 2013, 15 (1), 78-92.

(8) Liu, J. F.; Zhao, Z. S.; Jiang, G. B. Coating $\mathrm{Fe}_{3} \mathrm{O}_{4}$ Magnetic Nanoparticles with Humic Acid for High Efficient Removal of Heavy Metals in Water. Environ. Sci. Technol. 2008, 42 (18), 6949-6954.

(9) Liu, J.; Hurt, R. H. Ion Release Kinetics and Particle Persistence in Aqueous Nano-Silver Colloids. Environ. Sci. Technol. 2010, 44 (6), 2169-2175.

(10) Metal Speciation and Bioavailability in Aquatic Systems; Tessier, A., Turner, D. R., Eds.; John Wiley \& Sons: Chichester, 1995.

(11) Van Leeuwen, H. P.; Town, R. M.; Buffle, J.; Cleven, R.; Davison, W.; Puy, J.; van Riemsdijk, W. H.; Sigg, L. Dynamic Speciation Analysis and Bioavailability of Metals in Aquatic Systems. Environ. Sci. Technol. 2005, 39 (22), 8545-8556.

(12) Sigg, L.; Black, F.; Buffle, J.; Cao, J.; Cleven, R.; Davison, W.; Galceran, J.; Gunkel, P.; Kalis, E.; Kistler, D.; Martin, M.; Noel, S.; Nur, Y.; Odzak, N.; Puy, J.; Van Riemsdijk, W.; Temminghoff, E.; Tercier-Waeber, M. L.; Toepperwien, S.; Town, R. M.; Unsworth, E.; Warnken, K. W.; Weng, L. P.; Xue, H. B.; Zhang, H. Comparison of Analytical Techniques for Dynamic Trace Metal Speciation in Natural Freshwaters. Environ. Sci. Technol. 2006, 40 (6), 1934-1941.

(13) Limbach, L. K.; Wick, P.; Manser, P.; Grass, R. N.; Bruinink, A.; Stark, W. J. Exposure of Engineered Nanoparticles to Human Lung Epithelial Cells: Influence of Chemical Composition and Catalytic Activity on Oxidative Stress. Environ. Sci. Technol. 2007, 41 (11), $4158-4163$.

(14) Wang, Z.; Liu, S.; Ma, J.; Qu, G.; Wang, X.; Yu, S.; He, J.; Liu, J.; Xia, T.; Jiang, G.-B. Silver Nanoparticles Induced RNA PolymeraseSilver Binding and RNA Transcription Inhibition in Erythroid Progenitor Cells. ACS Nano 2013, 7 (5), 4171-4186.

(15) Xia, T.; Kovochich, M.; Liong, M.; Maedler, L.; Gilbert, B.; Shi, H.; Yeh, J. I.; Zink, J. I.; Nel, A. E. Comparison of the Mechanism of Toxicity of Zinc Oxide and Cerium Oxide Nanoparticles Based on Dissolution and Oxidative Stress Properties. ACS Nano 2008, 2 (10), 2121-2134.

(16) Muller, K. H.; Kulkarni, J.; Motskin, M.; Goode, A.; Winship, P.; Skepper, J. N.; Ryan, M. P.; Porter, A. E. pH-Dependent Toxicity of High Aspect Ratio $\mathrm{ZnO}$ Nanowires in Macrophages Due to Intracellular Dissolution. ACS Nano 2010, 4 (11), 6767-6779.

(17) Shen, M. H.; Zhou, X. X.; Yang, X. Y.; Chao, J. B.; Liu, R.; Liu, J. F. Exposure Medium: Key in Identifying Free $\mathrm{Ag}^{+}$as the Exclusive Species of Silver Nanoparticles with Acute Toxicity to Daphnia magna. Sci. Rep. 2015, 5, 9674.

(18) Thomas, C. R.; George, S.; Horst, A. M.; Ji, Z.; Miller, R. J.; Peralta-Videa, J. R.; Xia, T.; Pokhrel, S.; Maedler, L.; GardeaTorresdey, J. L.; Holden, P. A.; Keller, A. A.; Lenihan, H. S.; Nel, A. E.; Zink, J. I. Nanomaterials in the Environment: From Materials to HighThroughput Screening to Organisms. ACS Nano 2011, 5 (1), 13-20.

(19) Benn, T. M.; Westerhoff, P. Nanoparticle Silver Released into Water from Commercially Available Sock Fabrics. Environ. Sci. Technol. 2008, 42 (11), 4133-4139.

(20) Navarro, E.; Piccapietra, F.; Wagner, B.; Marconi, F.; Kaegi, R.; Odzak, N.; Sigg, L.; Behra, R. Toxicity of Silver Nanoparticles to Chlamydomonas reinhardtii. Environ. Sci. Technol. 2008, 42 (23), 8959-8964.

(21) Kittler, S.; Greulich, C.; Diendorf, J.; Koeller, M.; Epple, M. Toxicity of Silver Nanoparticles Increases during Storage Because of Slow Dissolution under Release of Silver Ions. Chem. Mater. 2010, 22 (16), 4548-4554.

(22) Cornelis, G.; Kirby, J. K.; Beak, D.; Chittleborough, D.; McLaughlin, M. J. A Method for Determination of Retention of Silver and Cerium Oxide Manufactured Nanoparticles in Soils. Environ. Chem. 2010, 7 (3), 298-308.

(23) Xiu, Z. M.; Ma, J.; Alvarez, P. J. J. Differential Effect of Common Ligands and Molecular Oxygen on Antimicrobial Activity of Silver Nanoparticles versus Silver Ions. Environ. Sci. Technol. 2011, 45 (20), 9003-9008.

(24) Liu, J. F.; Chao, J. B.; Liu, R.; Tan, Z. Q.; Yin, Y. G.; Wu, Y.; Jiang, G. B. Cloud Point Extraction as an Advantageous Preconcentra- tion Approach for Analysis of Trace Silver Nanoparticles in Environmental Waters. Anal. Chem. 2009, 81 (15), 6496-6502.

(25) Chao, J. B.; Liu, J. F.; Yu, S. J.; Feng, Y. D.; Tan, Z. Q.; Liu, R.; Yin, Y. G. Speciation Analysis of Silver Nanoparticles and Silver Ions in Antibacterial Products and Environmental Waters via Cloud Point Extraction-Based Separation. Anal. Chem. 2011, 83 (17), 6875-6882.

(26) Yu, S. J.; Chao, J. B.; Sun, J.; Yin, Y. G.; Liu, J. F.; Jiang, G. B. Quantification of the Uptake of Silver Nanoparticles and Ions to HepG2 Cells. Environ. Sci. Technol. 2013, 47 (7), 3268-3274.

(27) Su, S.; Chen, B.; He, M.; Xiao, Z.; Hu, B. A Novel Strategy for Sequential Analysis of Gold Nanoparticles and Gold Ions in Water Samples by Combining Magnetic Solid Phase Extraction with Inductively Coupled Plasma Mass Spectrometry. J. Anal. At. Spectrom. 2014, 29 (3), 444-453.

(28) Geranio, L.; Heuberger, M.; Nowack, B. The Behavior of Silver Nanotextiles during Washing. Environ. Sci. Technol. 2009, 43 (21), $8113-8118$

(29) Ngeontae, W.; Janrungroatsakul, W.; Morakot, N.; Aeungmaitrepirom, W.; Tuntulani, T. New Silver Selective Electrode Fabricated from Benzothiazole Calix[4] arene: Speciation Analysis of Silver Nanoparticles. Sens. Actuators, B 2008, 134 (2), 377-385.

(30) Maurer-Jones, M. A.; Mousavi, M. P. S.; Chen, L. D.; Buehlmann, P.; Haynes, C. L. Characterization of Silver Ion Dissolution from Silver Nanoparticles Using Fluorous-Phase IonSelective Electrodes and Assessment of Resultant Toxicity to Shewanella oneidensis. Chem. Sci. 2013, 4 (6), 2564-2572.

(31) Van Der Veeken, P. L. R.; Pinheiro, J. P.; Van Leeuwen, H. P. Metal Speciation by DGT/DET in Colloidal Complex Systems. Environ. Sci. Technol. 2008, 42 (23), 8835-8840.

(32) Degueldre, C.; Favarger, P. Y.; Wold, S. Gold Colloid Analysis by Inductively Coupled Plasma-Mass Spectrometry in a Single Particle Mode. Anal. Chim. Acta 2006, 555 (2), 263-268.

(33) Laborda, F.; Jimenez-Lamana, J.; Bolea, E.; Castillo, J. R. Selective Identification, Characterization and Determination of Dissolved Silver(I) and Silver Nanoparticles Based on Single Particle Detection by Inductively Coupled Plasma Mass Spectrometry. J. Anal. At. Spectrom. 2011, 26 (7), 1362-1371.

(34) Pace, H. E.; Rogers, N. J.; Jarolimek, C.; Coleman, V. A.; Gray, E. P.; Higgins, C. P.; Ranville, J. F. Single Particle Inductively Coupled Plasma-Mass Spectrometry: A Performance Evaluation and Method Comparison in the Determination of Nanoparticle Size. Environ. Sci. Technol. 2012, 46 (22), 12272-12280.

(35) Römer, I.; White, T. A.; Baalousha, M.; Chipman, K.; Viant, M. R.; Lead, J. R. Aggregation and Dispersion of Silver Nanoparticles in Exposure Media for Aquatic Toxicity Tests. J. Chromatogr. A 2011, 1218 (27), 4226-4233.

(36) Poda, A. R.; Bednar, A. J.; Kennedy, A. J.; Harmon, A.; Hull, M.; Mitrano, D. M.; Ranville, J. F.; Steevens, J. Characterization of Silver Nanoparticles Using Flow-Field Flow Fractionation Interfaced to Inductively Coupled Plasma Mass Spectrometry. J. Chromatogr. A 2011, 1218 (27), 4219-4225.

(37) Nischwitz, V.; Goenaga-Infante, H. Improved Sample Preparation and Quality Control for the Characterisation of Titanium Dioxide Nanoparticles in Sunscreens Using Flow Field Flow Fractionation on-line with Inductively Coupled Plasma Mass Spectrometry. J. Anal. At. Spectrom. 2012, 27 (7), 1084-1092.

(38) Pettibone, J. M.; Gigault, J.; Hackley, V. A. Discriminating the States of Matter in Metallic Nanoparticle Transformations: What Are We Missing? ACS Nano 2013, 7 (3), 2491-2499.

(39) Soto-Alvaredo, J.; Montes-Bayón, M.; Bettmer, J. Speciation of Silver Nanoparticles and Silver(I) by Reversed-Phase Liquid Chromatography Coupled to ICPMS. Anal. Chem. 2013, 85 (3), $1316-1321$.

(40) Zhou, X. X.; Liu, R.; Liu, J. F. Rapid Chromatographic Separation of Dissoluble $\mathrm{Ag}(\mathrm{I})$ and Silver-Containing Nanoparticles of 1-100 Nanometer in Antibacterial Products and Environmental Waters. Environ. Sci. Technol. 2014, 48 (24), 14516-14524.

(41) Franze, B.; Engelhard, C. Fast Separation, Characterization, and Speciation of Gold and Silver Nanoparticles and Their Ionic 
Counterparts with Micellar Electrokinetic Chromatography Coupled to ICP-MS. Anal. Chem. 2014, 86 (12), 5713-5720.

(42) Parthasarathy, N.; Buffle, J. Capabilities of Supported Liquid Membranes for Metal Speciation in Natural-Waters - Application to Copper Speciation. Anal. Chim. Acta 1994, 284 (3), 649-659.

(43) Tomaszewski, L.; Buffle, J.; Galceran, J. Theoretical and Analytical Characterization of a Flow-through Permeation Liquid Membrane with Controlled Flux for Metal Speciation Measurements. Anal. Chem. 2003, 75 (4), 893-900.

(44) Slaveykova, V. I.; Parthasarathy, N.; Buffle, J.; Wilkinson, K. J. Permeation Liquid Membrane as a Tool for Monitoring Bioavailable $\mathrm{Pb}$ in Natural Waters. Sci. Total Environ. 2004, 328 (1-3), 55-68.

(45) Romero, R; Jönsson, J. Å. Determination of Free Copper Concentrations in Natural Waters by Using Supported Liquid Membrane Extraction under Equilibrium Conditions. Anal. Bioanal. Chem. 2005, 381 (7), 1452-1459.

(46) Romero, R.; Liu, J. F.; Mayer, P.; Jönsson, J. Å. Equilibrium Sampling through Membranes of Freely Dissolved Copper Concentrations with Selective Hollow Fiber Membranes and the Spectrophotometric Detection of a Metal Stripping Agent. Anal. Chem. 2005, 77 (23), 7605-7611.

(47) Unsworth, E. R.; Warnken, K. W.; Zhang, H.; Davison, W.; Black, F.; Buffle, J.; Cao, J.; Cleven, R.; Galceran, J.; Gunkel, P.; Kalis, E.; Kistler, D.; Van Leeuwen, H. P.; Martin, M.; Noel, S.; Nur, Y.; Odzak, N.; Puy, J.; Van Riemsdijk, W.; Sigg, L.; Temminghoff, E.; Tercier-Waeber, M. L.; Toepperwien, S.; Town, R. M.; Weng, L. P.; Xue, H. B. Model Predictions of Metal Speciation in Freshwaters Compared to Measurements by in Situ Techniques. Environ. Sci. Technol. 2006, 40 (6), 1942-1949.

(48) Tan, Z. Q.; Liu, J. F. Visual Test of Subparts per Billion-Level Mercuric Ion with a Gold Nanoparticle Probe after Preconcentration by Hollow Fiber Supported Liquid Membrane. Anal. Chem. 2010, 82 (10), 4222-4228.

(49) Liu, J. F.; Jönsson, J. Å.; Mayer, P. Equilibrium Sampling through Membranes of Freely Dissolved Chlorophenols in Water Samples with Hollow Fiber Supported Liquid Membrane. Anal. Chem. 2005, 77 (15), 4800-4809.

(50) Lee, J.; Lee, H. K.; Rasmussen, K. E.; Pedersen-Bjergaard, S. Environmental and Bioanalytical Applications of Hollow Fiber Membrane Liquid-Phase Microextraction: A Review. Anal. Chim. Acta 2008, 624 (2), 253-268.

(51) Liu, J. F.; Toräeng, L.; Mayer, P.; Jönsson, J. Å. Passive Extraction and Clean-up of Phenoxy Acid Herbicides in Samples from a Groundwater Plume Using Hollow Fiber Supported Liquid Membranes. J. Chromatogr. A 2007, 1160 (1-2), 56-63.

(52) Tolessa, T.; Liu, J. Application of Negligible and Full Depletion Micro-Extraction in Environmental Science. Trends Environ. Anal. Chem. 2015, 6, 10-20.

(53) Guyon, F.; Parthasarathy, N.; Buffle, J. Mechanism and Kinetics of Copper(II) Transport through Diaza-Crown Ether Fatty AcidSupported Liquid Membrane. Anal. Chem. 1999, 71 (4), 819-826. 